\title{
WHAT WAS MARGARET THATCHER'S LEGACY FOR WOMEN?
}

\author{
June Purvis, University of Portsmouth, UK \\ Published in Women's History Review, Vol 22, No 6, December 2013, pp. 1014-1018, \\ http://dx.doi.org/10.1080/09612025.2013.801136
}

\section{ABSTRACT}

This article considers the legacy for women of Margaret Thatcher (1925-2013), Britain's first and to date only Prime Minister. It is suggested that although Thatcher had to struggle against many of the sexist prejudices of her day to achieve her political ambitions, she was no feminist. The hard ladder up which she had climbed was drawn up and not extended to other women. Yet for some women, such as the Spice Girls, she was the pioneer of their ideology of girl power. Overall, it is concluded that Thatcher was a polarising figure whose legacy is one of much divisiveness in which the divisions between women is only one strand.

\section{BIOGRAPHICAL DATA}

June Purvis is Professor of Women's and Gender History at the University of Portsmouth, UK. She is the Founding and Managing Editor of Women's History Review. She has published extensively on women's education in nineteenth-century Britain and on the British suffragette movement in the Edwardian era. Her most recent book, co-edited with Francisca de Haan, Margaret Allan and Krassimira Daskalova is Women's Activism: global perspectives from the 1890s to the present (Routledge, 2013). Correspondence to: June Purvis, School of Social, Historical and Literary Studies, University of Portsmouth, Burnaby Road, Portsmouth PO1 3AS, UK. Email: june.purvis@port.ac.uk

The death of Margaret Thatcher, Britain's first and to date only female Prime Minister, on Monday $8^{\text {th }}$ April 2013, was widely covered in the British and international media. Since Christmas 2012 she had lived at the Ritz in London, looked after by her care staff and the staff at the hotel. Her years since the death of her husband, Denis, in 2003, had been increasingly lonely. Dementia crept in and it is said that she used to talk to Denis, an aspect of her later life portrayed in the feature film The Iron Lady, directed by Phyllida Lloyd with screen play by Abi Morgan. On hearing of Thatcher's death, Gerri Halliwell, one of the singers of the former pop group the Spice Girls, tweeted 'Thinking of our 1st Lady of girl power, Margaret Thatcher, a grocer's daughter who taught me anything is possible.' A large number of Halliwell's 200,000 followers were so put out with what she wrote, she withdrew the tweet. What was Margaret Thatcher's legacy for women?

An outsider in terms of her gender and social class, Margaret Thatcher had to struggle against many of the sexist prejudices of her day within the Conservative Party, of which she was a member, and within the male dominated parliamentary system generally. When she first entered parliament in 
1959 , she was only one of two dozen MPs out of a total of over 600. Unusually for a woman MP at that time, she was the young mother of six-year-old twins. Like many modern woman today she juggled employment and motherhood and, importantly, could afford to pay for good childcare. Some eight years earlier, at the age of 26 , she had made a wise choice when she married the amiable, wealthy Denis Thatcher, a businessman. Denis never felt threatened by his wife's ambitions but was always a strong emotional support for her, something that was critical for her future success. Born Margaret Roberts, in 1925, to Alderman Alfred Roberts, a grocer, and his wife, Beatrice, the new MP had none of the influential networks that aided so many of her male Conservative peers. But she had learnt well the values of hard work, self-discipline and thrift, taught to her by her devout Methodist parents. Her father, a Methodist lay preacher and mayor of the provincial town of Grantham, Lincolnshire, undoubtedly passed onto his younger daughter - who remained a committed Christian all her life - a sense of public service. Margaret Roberts was determined to succeed.

A conscientious, clever child she had attended a girls' grammar school in her home town of Grantham, Lincolnshire. Then in 1943, during the Second World War, had won an exhibition to attend the all-women's college of Somerville, Oxford, where she read Chemistry, a subject that few women studied at that time. It was while at Somerville that Margaret Roberts joined the Conservative Association, a formative decision. Within two years of graduating, while working as a research scientist, she stood unsuccessfully for the Kent seat of Dartford. Despite this setback, the seed of parliamentary ambition had been sown. From now onwards, she was single minded and focussed in her aim to become an MP. Believing that a legal training would help her ambition, she decided to study law. In 1953, while still in the maternity hospital after giving birth to twins, Carol and Mark, she signed up to study for her bar finals and was called to the bar, at Lincoln's Inn, in 1954. In 1958, she was selected for the London constituency of Finchley, a safe Conservative seat that she won the following year. This made it easier for her to combine her parliamentary work with family life.

In 1961, after only 20 months on the backbenches, Thatcher was made a junior pensions minister under the then Prime Minister, Harold Macmillan. In 1967, when the Conservatives were in opposition, she was promoted to the shadow cabinet by the new party leader, Edward Heath. When Heath won the general election of 1970, she was appointed Education Secretary, the only woman in the cabinet. As Heath's government went from crisis to crisis, with a miner's overtime ban, power cuts and a three-day working week, he lost the next general election. Margaret Thatcher, in opposition, then became in 1975 the first woman leader of the Conservatives, a position many in her party resented. Neither did the Labour Government of the time, led by James Callaghan, rate her highly. But forged in the macho atmosphere of parliamentary politics, Thatcher was observing and learning. After the 1978 so-called 'winter of discontent', the Callaghan government fell and she was returned to parliament in 1979, the first female Prime Minister of Britain, and the first woman to lead a major Western power. Since criticisms about her clothes, hair and voice were frequently made, in a highly sexist way, she was advised to soften her appearance and to take voice coaching lessons, which she did. Margaret Thatcher became an important role model for some aspiring woman, a woman who succeeded against all the odds, in a man's world. 
But the tough, determined Margaret Thatcher, was a disappointment to many other women. She was no feminist and indeed once said that feminism was poison. Since she saw no reason to see women as a separate entity to men, she did not pursue women-friendly policies, for example, in regard to childcare, nursery provision or equal pay. A conviction politician with a very strong belief that she was right, Thatcher liked confrontation and argument rather than a consensual style of leadership. She did not promote able Conservative women into her cabinet, Baroness Young, the Leader of the House of Lords, being the only woman to hold office under her premiership of eleven and a half years. The hard ladder up which she had climbed was drawn up and not extended to other women. Thatcher liked to exercise power, but in an elitist rather than egalitarian way. She enjoyed being surrounded by men, like a Queen Bee, particularly with men who would argue with her. The aristocratic grandees of the old Conservative Right, who believed in one-nation politics, were dismissed as 'wets'.

It has often been said that her femininity was partly the key to her success. In particular, that many male Conservative MPs, brought up authoritative women such as nannies and distant mothers, found it difficult to challenge her. Some men even wrote about her sex appeal, as did Alan Clark, a Conservative MP and notorious womaniser, who jotted in his diaries that he was distracted by her ankles when she stood at the dispatch box. For the French President Francoise Mitterrand, on the other hand, Margaret Thatcher was both sexy and terrifying, with 'the eyes of Caligula and the mouth of Marilyn Monroe'. Be that as it may, such factors alone could not account for her parliamentary dominance and return to power in three general elections, making her the longest serving British prime minister of the twentieth century. Any discussion of Thatcher's parliamentary success cannot ignore the lamentable state of the opposition at this time. The Labour Party was weak and divided, plagued by infighting and the lunacy of the far left. Tired of the disarray, Shirley Williams and three other colleagues left to form the breakaway Social Democratic Party.

Yet many of the personal characteristics that made Margaret Thatcher such a towering force in British politics served her well when in 1982, Argentina under the dictatorship of General Galtieri, invaded the Falkland Islands, British territory some 6,000 miles away from London, in the South Atlantic. She resolutely refused to be persuaded by the cabinet to negotiate a settlement and took the considerable risk of ordering the assembling of a task force to take back the Islands. That victory enhanced her status on the world stage. Too many on the left had betrayed the Islanders, arguing that they had no right to self determination and were merely 'Little Britons', waving their Union Jacks. What did it matter if Argentina wanted a group of islands full of tussock, bog and penguins? Was not the class war against Thatcher the more important war to fight? Thatcher, through her support of the Falklands Islanders, upheld the principle of democracy. What was more, through her action she brought down the obnoxious dictatorship of Galtieri.

Thatcher's belief that tyrannous and oppressive political systems must be fought has been underplayed in assessments of her legacy. In Ronald Reagan, the American President, she found a friend who shared her hatred of Soviet communism. In the 1980s, she had the insight to make contact with a relatively unknown moderniser in the Soviet Politburo, Mikhail Gorbachev, a man with whom she said she could do business. When Thatcher visited Russia in 1987, she was mobbed by the public who saw her as upholding those freedoms they so desperately wanted. She helped to bring about an end to the Cold War and the totalitarian regimes of the Eastern bloc. Yet no support 
appears to have been offered to the African National Congress (ANC), fighting the evil of apartheid in South Africa. Without hesitation, she called the ANC a terrorist organisation and would not support the imposition of sanctions against that country.

Despite considerable success on the international stage, Thatcher's domestic policies at home made her a divisive, polarising figure. Determined to do something about the many strikes that had plagued Britain in the 1960s and 70s, earning it the name of the 'sick man of Europe', she decided to tackle what she called 'the enemy within' with a harshness that shocked the British people. She rolled back the state, introduced privatisation of state-owned utilities, and supported a free market economy. The introduction of cuts to university funding and of the first student loans, demoralised academic staff and depressed the aspirations of many able young women and men seeking academic careers. The closure of many coal mines in the 1980s involved not only a loss of jobs but also the destruction of communities. TV footage of mounted police beating those who were fighting for their livelihoods and way of life are still shocking to watch. As unemployment rose to over three million, Thatcher with her determination to push through the policies she believed in, seemed indifferent to the personal hardships of many ordinary people. She became a hate figure in many working-class communities, especially in Wales, Scotland and the North of England. The trade unions, which needed to be sorted out for the way they were profoundly undemocratic and sexist, often bargaining away women's rights, were subjected to various employment acts. Secret ballots in which every union member, including women, had a vote on strike action, were brought in. The closed shop tradition of trade unions was ended. The old postwar consensus that governments would negotiate with the unions was gone. Additionally, the special friendship between Britain and America, which Thatcher had helped to maintain, led to her announcement in 1980 that American Cruise missiles would be placed on British soil, at the RAF base at Greenham Common. Greenham became a focus of campaigning for anti-nuclear women's groups.

The decision of an over-confident Margaret Thatcher to try to push through the poll tax which would have levelled a tax on every citizen within a household rather than on the house itself, was her undoing. If implemented, it would have meant that large families would pay much more than under the old system of rates on house values. Protests and riots took place in a number of cities. She was ignobly pushed out of office by her own Cabinet, not the electorate who had voted her in three times.

There is no doubt that Margaret Thatcher changed the political landscape of Britain - and forced a transformation in the Labour Party too which, as 'New Labour', came to power in 1997 under Prime Minister Tony Blair. New Labour sought to win the centre ground by seeking some sort of 'Third Way' between socialism and capitalism. The commitment to nationalisation and state control was ditched, and market economics endorsed. Employment legislation passed by the Conservatives was almost untouched. Thatcher often said that her greatest legacy was New Labour, and Tony Blair, which for many on the left is highly problematic. But what of her legacy for women? For some, such as the Spice Girls, she was the pioneer of their ideology of girl power. But for many other women she was a regressive force. Margaret Thatcher's rise from a grocer's shop to death at the Ritz is a story of much divisiveness in which the divisions between women is only one strand. 
NOTE: I would like to thank the two referees who commented on this article in record time. Special thanks is also due to Wendy Webster who made insightful comments. However, any errors remain mine own. 